\title{
Dakwah Terhadap Kaum Milenial Melalui Akun Facebook Motivasi Hijrah
}

\author{
Anih Ai Aisyah ${ }^{1 *}$, Tjetjep Fachruddin ${ }^{1}, \&$ Acep Aripudin ${ }^{2}$ \\ ${ }^{1} J u r u s a n$ Komunikasi dan Penyiaran Islam, Fakultas Dakwah dan Komunikasi, \\ UIN Sunan Gunung Djati, Bandung \\ ${ }^{2}$ Prodi Komunikasi dan Penyiaran Islam, Program Pascasarjana, \\ UIN Sunan Gunung Djati, Bandung \\ *Email: anihaisyah5242@gmail.com
}

\begin{abstract}
This study aims to find out the da'wah messages for millenials on facebook social media migration motivation. The research focused on the meaning of denotation and the meaning of message connotation in the hijrah motivational facebook account and how the meaning of missionary message myth in the same account. The method used by researchers is semiotics in teh form of data analysis, by processing and interpreting quotes to provide on overview of the development of facebook as a medium that provides motivation. Linking quotes with the reality of life that is able to provide implicit meaning as a missionary message behind the posting of hijrah motivational accounts. The results of the study show that the form of da'wah activities carried out by hijrah motivational accounts can provide preaching messages for millenials. Use unique images to influence the attentoin of millenials in migrating. Facebook is used as a medium to understand missionary messages for millenials as a smooth learning process to accept islamic messages.
\end{abstract}

Keywords: da'wah; millenial; hïrah motivational

\begin{abstract}
ABSTRAK
Penelitian ini bertujuan mengetahui pesan dakwah untuk kaum milenial di media sosial facebook. Motivasi Hijrah. Penelitian difokuskan pada makna denotasi dan konotasi pesan dalam akun facebook Motivasi Hijrah dan bagaimana makna mitos pesan dakwah dalam akun yang sama. Metode yang digunakan peneliti adalah semiotik yang berbentuk analisis data, dengan mengolah dan menafsirkan quote untuk memberikan gambaran mengenai perkembangan facebook sebagai media yang memberikan motivasi. Menghubungkan quote dengan realita (reality) kehidupan yang mampu memberikan makna tersirat sebagai pesan dakwah di balik postingan akun Motivasi Hijrah. Hasil penelitian menunjukan bahwa bentuk kegiatan dakwah yang dilakukan oleh akun Motivasi Hijrah dapat memberikan pesan dakwah bagi kalangan milenial. Menggunakan gambar-gambar unik untuk mempengaruhi perhatian kalangan milenial dalam melakukan hijrah. Facebook dijadikan sebagai media untuk memahami pesan dakwah bagi kalangan milenial
\end{abstract}


A. A. Aisyah, T. Fachruddin, \& A. Aripudin

sebagai proses pembelajaran yang berkesan halus untuk menerima pesan keislaman.

Kata Kunci : dakwah; milenial; motivasi hijrah

\section{PENDAHULUAN}

Dakwah merupakan aktualisasi diri dengan melibatkan unsur-unsur yang ada di dalamnya. Melihat perkembangan budaya dakwah dianggap penting oleh masyarakat, sehingga da'i berusaha menyampaikan dakwah dengan mempertimbangkan konteks masyarakat tersebut. Generasi baru butuh motivasi melalui dakwah yang mempengaruhi pikiran dan emosi mereka dengan media digital, seperti facebook.

Para Penggiat dakwah merupakan orang yang mampu membimbing ajaran keislaman bagi setap manusia, menggambarkan dan mentranfer pemahaman yang mereka ketahui untuk diberikan kepada umat yang lain agar keilmuan mampu berputar sesuai porsi yang dibutuhkan. Menjalankan kewajiban saling mentransfer wasiat yang seharusnya dijalankan sebagai bentuk kegiatan dakwah Islam (Budiman, 2018:182).

Maka dari itu berdakwah memerlukan media yang mendukung untuk melakukan penyebaran tema-tema keislaman, apalagi saat ini teknologi semakin berkembang pesat ketimbang manusianya, sehingga pemanfaatan media digital semakin dibutuhkan untuk membantu mempermudah penyebaran. Salah satunya media sosial, yang dijadikan sebagai salah satu media penunjang proses penyebaran keislaman yang banyak digunakan oleh kalangan milenial.

Kehadiran media sosial banyak membantu kalangan milenial untuk melalukan interaksi sekaligus mendapatakan informasi untuk mereka pahami secara cepat dalam memecahkan sesuatu. Pemanfaatan media yang digunakan untuk menerima berbagai informasi bersifat halus dan tidak terkesan kaku, sehingga bisa diterima oleh kalangan milenial.

Pemanfatan media sosial dijadikan sebagian kalangan milenial untuk menjalankan aktivitas dakwah yang lebih terkesan santai namun memberikan efek yang bermanfaat, internet dijadikan sebagai jalan untuk menjebatani kegiatan dakwah yang dilakukan secara rutin oleh kalangan milenial itu sendiri (Ismail, 2018: 24)

Penggunaan alat modern berusaha membuat orang mencapai kemakmuran melalui cara mengembangkan banyak media, sehingga penyampaian suatu pesan politik, kesehatan, keagamaan dan lainnya bisa dilakukan secara instan. Dalam bidang keagamaan media sosial dianggap sebagai bagian untuk menyampaikan pesan kegiatan keislaman, seperti facebook, twetter, instagram dan youtube. Salah satunya akun facebook "Motivasi Hijrah" yang berusaha menyampaikan suatu pesan lewat sebuah gambar.

"Motivasi Hijrah" adalah salah satu akun yang ada di facebook, dimana setiap postingan bersifat mengajak kepada masyarakat luas untuk beristiqamah dalam 
perjalanan hijrah (pindah). Postingannya menyuguhkan tulisan dan gambar yang sifatnya lebih terkesan santai. Bacaan yang ringan, ditampilkan bagi pengguna untuk mendapatkan informasi lebih singkat dari biasanya.

Respon pertama dari pesan yang disampaikan akun Motivasi Hijrah mendapatkan 106 suka, 37 komentar, dan 16 kali postingan terbagikan. Postingan yang disuguhkan oleh akun "Motivasi Hijrah" banyak mendapatkan "like" dan komentar dari para pembaca. Bahkan, banyak orang yang ikut membagikan postingannya.

Meskipun akun "Motivasi Hijrah" masih terbilang baru, namun orang yang menyukai akun ini sudah mencapai 17.048 orang. Sedangkan yang mengikutinya sebanyak 17.722 orang dan akan terus bertambah (https://m.facebook.com/home.php). Pengikut akun "Motivasi Hijrah" rata-rata anak muda yang masih berproses untuk memakai kerudung, dan berproses meninggalkan "pacaran”. Meskipun secara faktanya kebanyakan dari mereka baru men-share tulisan. Hal itu dilihat dari sebagian akun pribadi yang mengikuti akun "Motivasi Hijrah" (Sumber: wawancara dengan pemilik akun facebook Motivasi Hijrah via Mesengger dan WhatApp pada tanggal 18 Oktober 2018-7 Februari 2019).

Kata motivasi berasal dari bahasa Latin "Movere", mempunyai arti to move. Dijadikan sebagai proses untuk membangkitkan, mengarahahkan, dan mempertahankan perilaku manusia untuk mencapai beberapa tujuan (Tjandra, 2011:18-19). Sedangkan hijrah (pindah) sebagai cara seseorang untuk melakukan sesuatu sesuai dengan zaman orang-orang terdahulu, seperti para Nabi khususnya melakukan berdakwah. Melepaskan diri untuk kebenaran, yaitu sebuah keadaan ketika orang menjalankan kehidupan berdasarkan Alqur'an (Syamsudini, 2006:178).

Media sosial dijadikan sebagai penunjang bagi masyarakat untuk menyampaikan pesan-pesan kebaikan. Kemajuan teknologi mampu memajukan suatu bangsa, yang memberikan efek tertentu kepada masyarakatnya. Seperti facebook, twetter, Instagram dan Youtube menjadi bahan percobaan bagi setiap orang mengakses serta memanfaatkan medianya (Tabroni, 2012: 152).

Pada dasarnya mereka menggunakan facebook untuk bertukar informasi lewat fitur-fitur yang disajikan oleh akun facebook sendiri, sehingga tidak jarang banyak informasi-informasi yang tersebar di media sosial. Mengikuti perkembangannya banyak pengguna memanfaatkan media sosial seperti facebook untuk menyampaikan dakwahnya yang lebih terkesan lembut dan tidak kaku seperti dakwah di mimbar.

Apalagi di era modern seperti sekarang banyak kaum milenial yang melek terhadap media sosial, sehingga bisa dimanfaatkan untuk proses penyampaian pesan kebaikan secara cepat. Pergerakan menyebarkan kebaikan secara instan untuk mereka pahami lebih cepat dari biasanya. Keberadaan generasi milenial ditandai dengan keakraban dalam mengoprasikan penggunaan media dan teknologi digital.

Perkembangan budaya digital mendorong pergeseran minat dan pola generasi milenial mencari literatur keislaman; dari literatur yang dicetak (printed 
A. A. Aisyah, T. Fachruddin, \& A. Aripudin

literature) ke literatur online (online literature). Generasi milenial lebih suka mengakses sumber-sumber pengetahuan keislaman melalui internet. Bahkan sumber-sumber tersebut bisa diakses melalui aplikasi smartphone seperti, Facebook, Instagram, Youtube dan Whatapp (Hasan, 2018: 270).

Seperti penelitian Nurasiah Ismail. (2017). Pesan Dakwah di Media Sosial Instagram: Analisis Semiotika Pesan Dakwah di Media Sosial Instaram. Penelitian dalam akun@nikabbarokah bertujuan memberikan semangat kepada remaja yang berpacaran agar tidak terjerumus kepada kemaksiatan. Persamaan dari yang diteliti, yaitu meneliti media sosial, dan menggunakan analisis semiotik. Perbedaannya media yang diteliti yaitu pendahulu meneliti instagram sedangkan peneliti sekarang meneliti facebook.

Temuan dalam akun @nikabbarokah memposting materi tentang memnataskan diri, hijrah, ta'aruf, pernikahan, dan rumah tangga. Membantu membuat event dakwah, dan menjalin kerjasama dengan folowers. Membantu menyelesaikan permasalahan kehidupan folowers-nya sesuai dengan kemampuan yang dimiliki pembuat akun dan teman-teman lainnya agar menuju proses menikah.

Dakwah merupakan proses mengajak atau menyeru secara terus-menerus (continue) kepada jalan yang baik, untuk menjalankan proses dan tujuan dakwah. Kegiatan dakwah berkembang secara berkala menyesuaikan perjalanan ruang dan waktu (Syamsudini dkk, 2004:5).

Dakwah berusaha menjadi bagian dari kegiatan yang melibatkan berbagai unsurnya dalam merealisasikan tujuannya. Seperti aktivitas dakwah berusaha menyentuh semua wilayah kalangan masyarakat, sehingga dakwah tidak hanya transfer ilmu pengetahuan tetapi dikaji untuk pengembangan dakwah (Basit, 2013:14).

Ada beberapa unsur yang harus ada dalam dakwah, unsur tersebut merupakan komponen-komponen yang terdapat dalam setiap kegiatan dakwah. Unsur-unsur tersebut seperti; da'i (pelaku dakwah), mad'u (mitra dakwah), maddah (materi), wasilah (media), thariqah (metode), dan atsar (efek dakwah) (Munir dan Ilahi, 2006:21).

Pertama Da’i (Pelaku Dakwah), merupakan orang yang menjalankan ajakan, melalui lisan, tulisan maupun perbuatan yang dapat dilakukan secara sendirisendiri, kelompok atau lewat organisasi/lembaga. Kedua Mad'u (Penerima Dakwah), yaitu mitra yang menjadi sasaran dakwah Islam, baik individu ataupun kelompok, baik yang telah beragama Islam atau tidak. Orang yang belum beragama Islam, dakwah dijadikan sebagai ajakan untuk mengikuti ajaran Islam, sedangkan untuk orang yang telah masuk Islam dakwah bertujuan untuk meningkatkan Iman, Islam dan Ihsan (Munir dan Ilaihi, 2015: 22-23).

Ketiga Maddah (Materi Dakwah), yaitu isi pesan atau materi yang disampaikan da'i kepada mad'u. Dalam hal ini yang menjadi maddah adalah ajaran Islam. Materi dakwah mencakup masalah akidah (keimanan), syari'ah, akhlak dan muamalah. Materi yang disampaikan berupa kegiatan yang berhubungan dengan 
permasaahan hubungan antara makhluk dengan Tuhannya, larangan, mengatur pergaulan hidup antara sesama manusia dalam rangka menaati perintah Allah (Ishaq dan Ashar, 2016:292). Keempat W asilah (Media), adalah alat yang digunakan untuk menyampaikan materi dakwah (ajaran Islam) kepada mad'u. Menyampaikan ajaran Islam dengan menggunakan berbagai wasilah (Munir dan Ilahi, 2006: 32).

Kelima Thariqah (Metode), merupakan suatu cara yang ditempuh dengan menentukan pencapaian dan penyelesaian suatu tujuan, pola pikir manusia, dan rencana sistem. Sedangkan dalam metode pengajaran ajaran Islam disebutkan bahwa metode merupakan suatu cara yang sistematis dan umum dalam menentukan pencarian kebenaran ilmiah (Munir dan Ilahi, 2006: 32).

Metode dakwah yang dilakukan yaitu menggunakan metode bi al-bikmah, Al-Mau'idza Al-Hasanah dan Wa jadilhum bi Al-Lati Hiya Absan. Penggunaan metode tersebut merupakan cara yang disuguhkan sesuai dengan ayat Alqur'an pada surat An-Nahl ayat 125.

Hikmah berarti keutamaan dari segala sesuatu, baik pengetahuan atau perbuatan. Hikmah juga diartikan sebagai sesuatu yang digunakan/diperhatikan akan kemudahan dan kemaslahatan yang besar atau lebih besar, serta menghentikan kemadharatan apabila terjadi sesuatu (Shihab, 2002: 386).

Dakwah bil hikmah berarti dakwah yang dilakukan secara bijak dengan memperhatikan situasi, suasana dan kondisi mad'u (muqtadha-al-hal). Menggunakan metode yang relevan dengan realitas sebagaimana keberadaan intelektual, suasana psikologi dan situasi kultural mad'u (Muhyiddin, 2002:164).

Mau'idra Al-Hasanah yaitu, nasehat dan pelajaran yang baik, berpaling dari perbuatan jelek dari tarbib dan tagrib (dorongan dan motivasi); keterangan, gaya bahasa, penjelasan, teladan, petutur, peringatan, pengarahan dan pencegahan secara sopan dan halus (Muhyiddin, 2002:165).

Kata al-mau'izhab terambil dari kata wa'az̧ha yang berarti nasihat. Mau'iz̧ah merupakan uraian menyentuh hati yang mengantarkan kepada kebaikan. Metode mau'iz̧hah dapat mengena hati sasaran apabila ucapan yang disampaikan disertai dengan keteladanan dan pengalaman dari orang yang memberikan ajakan (Shihab, 2002: 387).

Sedangkan Wa jadilhum bi Al-Lati Hiya Absan berasal dari kata jadilhum terambil dari kata jidal yang bermakna bukti atau diskusi yang mematahkan dalih lawan dan menjadikan tidak bertahan, baik pemaparan yang diterima semua orang atau hanya oleh lawan. Jidal terdiri dari tiga macam: Pertama buruk, yaitu disampaikan secara kasar, menggunakan dalih kurang tepat dan mengundang kemarahan. Kedua baik, yang disampaikan dengan sopan serta memberikan suatu dalih yang benar dan Ketiga terbaik disampaikan dengan baik, argumen benar dan membungkam lawan (Shihab, 2002: 387-388).

Keenam Atsar (Efek) Dakwah), Aktivitas dakwah yang dilakukan berupa materi, metode dan media pasti akan menimbulkan efek pada mad'u. Atsar (efek) dakwah disebut dengan feed back (umpan balik) dari proses dakwah terhadap perhatian para $d a$ i. Evalusi dan koreksi terhadap atsar dakwah harus dilaksankan 
secara radikal dan komprehersif atau tidak setengah-setengah (Munir dan Ilahi, 2006: 34).

Setiap aktivitas dakwah mempunyai tujuan tertentu, memungkinkan kegiatannya bervariatif sesuai dengan tujuannya, sehingga untuk kalangan milenial membutuhkan media sosial yang menggunakan sebuah flatform yang muncul di media siber. Media sosial tidak jauh berbeda karakteristiknya dengan media siber. Struktur media sosial terbangun yang terbentuk dalam jejaring atau internet.

Kehadiran internet dijadikan sebagai wadah untuk menampung gagasan para juru dakwah dalam melakukan penyebaran ajaran keislaman. Kegiatan demikian mendorong juru dakwah untuk menyebarkan keislamannya di ruang siber, seperti pesan singkat yang di sodorkan lewat status di facebook, tulisan e-book, blog, website, dan tayangan dakwah yang berupa ceramah seperti youtube (Muhaemin, 2017:346)

Media sosial menurut para ahli dari berbagai penelitian literatur yaitu, Pertama, Mandibergh (2012), mengatakan media sosial sebagai wadah untuk kerja sama antar sesama pengguna untuk menghasilkan konten (user generated content). Kedua, Van Djik (2013), media sosial sebagai flatform yang memfokuskan pada eksisitensi pengguna yang memfasilitasi untuk beraktifitas maupun berkolaborasi (Nasrullah, 2016:11).

Generasi ini identik dengan kemajuan teknologi, khususnya media sosial dan internet. Menurut penelitian Pew Research Center (2010) generasi milenail tidak dapat dilepaskan dari pemanfatan teknologi, terutama yang berhubungan dengan internet yang dianggap sebagai kebutuhan pokok (Sabani, 2018:96). Generasi milenial menganggap semua hal yang tersebar di media sosial sebagai respresentasi dari realita di dunia nyata, sehingga mereka tidak terima atau tersinggung dan harus melakukan sesuatu untuk meluruskan sesuai dengan pendapatnya (Sabani, 2018: 102).

Media sosial digunakan untuk memperbincangkan apa pun, dari yang remeh-temeh, misalnya klub sepak bola, gambar palsu, hingga hal-hal yang penting bagi kehidupan masyarakat, seperti pemilihan calon presiden, gubernur dan lainnya. Perubaan gaya hidup yang konsumtif sangat terlihat pada generasi modern atau generasi milenial (Millenial Generation). Generasi milenial merupakan generasi yang hidup bersamaan dengan teknologi digital yang masuk pada kehidupan (Hidayatullah, 2018: 240).

Generasi digital atau milenial memiliki otoritas atas diri masing-masing dalam menggunakan media-media yang mereka akses. Generasi milenial, mampu memperlihatkan pola-pola keberagaman khas yang dipengaruhi oleh teknologi. Internet dijadikan sebagai guru dan teman bagi masyarakat digital. Generasi digital merupakan mad'u kelompok baru yang menerima pesan dakwah dengan kosep kekinian. Masyarakat jejaring yang aktif dalam berkomentar, mengkritik dan melakukan kegiatan dakwah dengan melakukan share melalui flatform yang digunakan (Fakhruroji, 2017:33-34). 
Salah satu media yang digunakan oleh kalangan mienial yaitu, facebook. Menurut frasa katanya, bahwa facebook dapat diartikan sebagai buku muka. Secara faktanya facebook bukan hanya sekedar buku muka, namun menjadi salah satu situs jejaring sosial yang menghadirkan untuk penggunanya saling berinteraksi dengan pengguna lainnya untuk bertukar informasi dari seluruh dunia (https://id.m.wikipedia.org/wiki/facebook).

Facebook digunakan untuk menyebarluaskan suatu konten, seperti aktivitas atau pendapatan pengguna, profil, sebagai media yang memberikan ruang interaksi bagi komunitas dalam ruang sosial. Fasilitas di facebook seperti wall bisa dimanfaatkan untuk pengungkapan yang disaksikan/dialami, dan bercerita keadaan sekitar (Nasrullah, 2017:40).

Facebook digunakan sebagai salah satu jejaring yang memungkinkan membantu membagikan postingan-postingan yang dibuat oleh akun-akun yang mengangkat tema tertentu, seperti salah satunya akun Motivasi Hijrah yang berusaha mengangkat tema keislaman untuk disebarluaskan ke berbagai kalangan khususnya bagi kaum milenial yang selalu mengakses media sosial.

Munculnya keberadaan akun Motivasi Hijrah didirikan oleh Winanda yang beralamatkan di Gang Abadi Sekura Kabupaten Sambas Propinsi Kalimantan Barat. Akun yang banyak memberikan postingan keislaman lewat gambar-gambar dan tulisan yang di posting di halaman facebook-nya.

Maka berdasarkan latar belakang diatas dapat dirumusakan sebagai berikut. Bagaimana makna denotasi pada postingan akun Motivasi Hijrah? Bagaimana makna konotasi pada postingan akun Motivasi Hijrah? Bagaimana makna mitos pada postingan akun Motivasi Hijrah?

Metode yang digunakan dalam penelitian ini adalah metode kualitatif yaitu, penelitian yang mengahasilkan data deskriptif kata-kata tertulis ataupun secara lisan dari orang-orang yang diamati. Penelitian kualitatif menggunakan metode wawancara, pengamatan, dan pemanfaatan dokumen (Moleong, 1975:5). Kemudian untuk mendapatkan hasilnya dianalisis, diolah dan ditafsirkan menggunakan teori semiotik Roland Barthes dari setiap postingan yang ada dalam akun Motivasi Hijrah.

\section{HASIL DAN PEMBAHASAN}

Akun Motivasi Hijrah dimiliki oleh Winanda, yaitu pemilik akun facebook yang mengandung konten dakwah dalam penyajian postingannya. Winanda lahir di Sekura, pada tanggal 1 Juni 2002, adalah putri dari pasangan suami istri bernama Rusiana dan Erwin. Alamat lengkapnya berasal dari Gang Abadi Sekura Kabupaten Sambas Propinsi Kalimantan Barat. Winanda mengenyam pendidikan dasarnya di SDN 2 Teluk Keramat, dilanjutkan ke SMPN 1 Teluk Keramat dan Madrasah Aliyah Yasti Sekura.

Disamping kegiatan ekstrakulekuler yang bersifat umum, Winanda memilih untuk mengikuti kegiatan keagamaan sebagai daya gerak pencapainya, salah 
satunya kegiatan Tilawah. Kegiatan ekstrakulikuler di sekolahnya ada beberapa yang bersifat keagamaan, seperti Shalawat, Tilawah, dan Tahfidz.

Pemilik akun facebook Motivasi Hijrah menginginkan setiap perjalanan hidupnya menuai kebaikan dari apa yang ia lakukan di dunia nyata atau di media sosial yang ia pegang saat ini. Memberikan manfaat untuk sesama dan sekaligus memberikan informasi kepada khalayak yang melihat postingannya (Sumber: Wawancara dengan pemilik akun facebook Motivasi Hijrah tanggal 18 Oktober 2018-7 Februari 2019).

Akun facebook Motivasi Hijrah, merupakan sebuah akun yang bertujuan untuk mengajak orang banyak menuju jalan sesuai ajaran Islam. Beristiqamah dalam setiap perjalanan hijrahnya, dan mengamalkan kegiatan dakwah dengan hijrah yang dijalankan bersama-sama. Mendekatkan diri kepada Allah untuk menaati peraturannya dan menjauhi larangannya. Media yang digunakan untuk berdakwah akun Motivasi Hijrah memanfaatkan flatform media sosial, yaitu menggunakan facebook (https://m.facebook.com/home.php).

Akun facebook Motivasi Hijrah merupakan akun yang dirilis oleh Winanda, pada tahun 2018 dan mempublikasikan postingannya pada tanggal 03 februari pukul 20:54 dengan mendapat 106 suka 37 komentar dan 16 kali postingan terbagikan. Akun Motivasi Hijrah adalah akun milik pribadi yang digunakan untuk mengunggah foto, vidio dan tulisan lainnya. Namun dari kegiatan unggahan demikian Winanda akhirnya merubah akun facebook Motivasi Hijrah dengan konten-konten yang bersifat mengajak kepada kebaikan (https://m.facebook.com/home.php).

Penamaan akun Motivasi Hijrah berasal dari perjalanan Winanda sebagai pengelola akun Motivasi Hijrah, yang menjadikan akun tersebut sebagai jalan untuk mengistiqamahkan setiap perjalanan hidupnya. Motivasi berarti memberikan arahan, dorongan serta membantu seseorang untuk menuju suatu jalan yang lebih baik. Sedangkan Hijrah sendiri yaitu pindah, bergerak atau membebaskan diri dari hal-hal yang membuat rusak dan dikekang dalam kebelengguan yang salah.

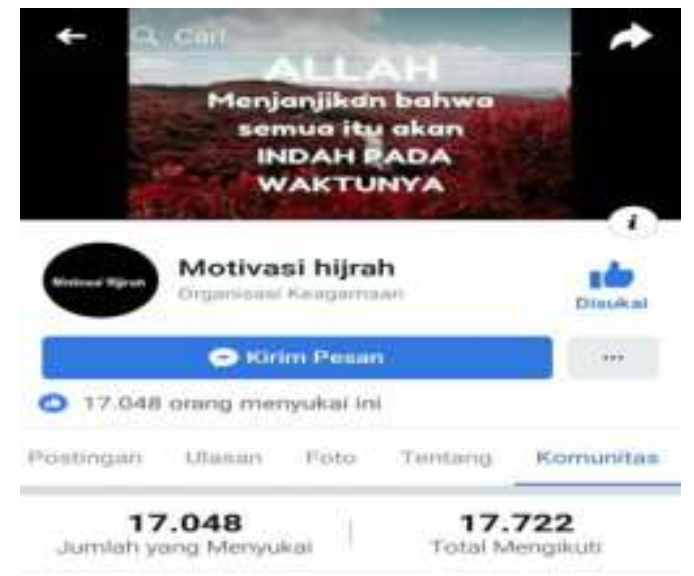


Dalam halaman awal berisi profil picture dengan logo yang bertuliskan warna putih dan memiliki background hitam bertuliskan Motivasi Hijrah dengan latar foto sampul memiliki background berwarna merah beralaskan gambar bukit. Gambar bertulisakan "Allah menjajikan bahwa semua itu akan indah pada waktunya".

Motivasi Hijrah merupakan salah satu dari sekian akun di facebook yang menyajikan konten-konten dengan mengandung ajakan dan seruan kepada kebaikan. Perbedaan akun Motivasi Hijrah dengan akun lainnya, yaitu penyampaian pesan dakwahnya disampaikan mengunakan bahasa konten sederhana dan jelas, sehingga pengikut bertambah. Pengikut akun Motivasi Hijrah terdiri dari kalangan orang dewasa dan remaja yang sedang berhijrah dan beristiqamah dalam perjalanan hijrahnya (https://m.facebook.com/home.php).

Akun Motivasi Hijrah setiap minggunya meng-update postingan gambar berupa quotes maupun pesan dakwah yang bersumber dari Alqur'an atau Hadits, kemudian ditambahkan dengan keterangan sebagai pelengkap keterangan foto. Pengikut akun Motivasi Hijrah mencapai 17.722 orang, sedangkan yang menyukai sebanyak 17.048 orang (https://m.facebook.com/home.php). Jumlah postingan pada bulan November dan Desember 2018 sebanyak 33 postingan konten dakwah Islam. Postingan bersifat akidah sebanyak 6 buah, postingan bersifat ibadah sebanyak 14, postingan yang bersifat akhlak sebanyak 13 dan postingan bersifat muamalah sebanyak 1 buah. Postingan yang di sebarluaskan diambil dari konten-konten islami dan cerita pribadi yang dikemas dengan tingkat kreatif yang berbeda.

\section{Hasil dan Pembahasan}

Analisis quote tentang dakwah terhadap kaum milenial akun facebook Motivasi Hijrah, telah diklasifikasikan terlebih dahulu menggunakan analisis semiotika Roalnd Barthes dengan menghasilkan makna denotasi, makna konotasi dan makna mitos. Quote yang mengandung pesan dakwah diunggah pada media sosial facebook pada bulan November dan Desember 2018.

Analisis semiotika Roland Barthes dinilai tepat untuk menganalisis makna quote yang ada pada akun facebook. Motivasi Hijrah analisis simbol melalui tiga tahap signifikasi. Jenis signifikasi yang pertama denotasi, hubungan antara signifier dan signified dalam sebuah tanda peneliti akan membahas makna yang terkandung dalam quote pasan dakwah untuk kaum milenial yang ada pada akun Motivasi Hijrah.

Tahap signifikasi kedua yaitu konotasi, peneliti mencoba mengartikan makna yang tidak langsung dalam quote pesan yang dianalisis. Sedangkan signifikasi tahap ketiga, yaitu makna mitos yang ada dalam quote pesan dakwah untuk kaum milenial. Peneliti mencoba mengemukakan makna mitos yang terkandung dalam analisis quote pesan dakwah hijrah untuk kaum milenial. 
Quote pesan dakwah tentang hijrah untuk kaum milenial yang ada pada akun facebook Motivasi Hijrah adalah quote tentang pesan-pesan dakwah yang berkaitan dengan postingan untuk milenial. Berdasarkan analisis penulis mengumpulkan data postingan yang bersifat akidah, ibadah, ahklak dan muamalah.

Postingan diklasifikasikan menggunakan makna denotasi, makna konotasi dan makna mitos Roland Barthes untuk menarik pesan dakwah yang ada pada akun facebook Motivasi Hijrah. Sedangkan untuk mengambil hasil klasifikasi pesan dakwah menggunakan empat kategori, yaitu pesan akidah, ibadah, akhlak, dan muamalah dan ditemukan 33 postingan.

Pesan dakwah akidah sebanyak 6 postingan yang di dalamnya membahas mengenai iman kepada Allah, qadha dan qadhar. Postingan yang diteliti sebanyak 5 dan yang tidak diteliti sebanyak 1 postingan. Pesan dakwah ibadah sebanyak 14 postingan yang di dalamnya membahas mengenai keutamaan seorang wanita yang berhijrah, beribadah kepada Allah sejak dini, keutamaan shalat tahajud, memohon ampunan perihal dosa-dosa, melakukan hijrah, ujian di dunia dan laki-laki yang siap menjalakan ibadah (menikah). Postingan yang diteliti sebanyak 7 dan yang tidak diteliti sebanyak 7 postingan.

Pesan dakwah akhlak sebanyak 13 postingan yang di dalamnya membahas mengenai larangan membentak seorang perempuan, larangan berbuat tabarruj, adab berdoa: larangan berdoa yang jelek-jelek untuk seorang anak, larangan berpacaran, memilki rasa malu, adab menundukan pandangan antar lawan jenis, dan memilih pasangan terbaik. Postingan yang diteliti sebanyak 7 dan yang tidak diteliti sebanyak 6 postingan. Pesan dakwah muamalah sebanyak 1 postingan di dalamnya membahas mengenai membimbing seorang istri dengan keimanan (ilmu) bukan dengan harta.

Dakwah menggunakan quote bagi kalangan milenial efektif digunakan di media sosial seperti facebook, twetter, instagram, dan youtube. Karena proses penyampaiannya bersifat halus dan tersebar luas untuk orang-orang yang fokus dengan dunia informasi seperti kalangan milenial.

Berdasarkan fokus penelitian dan analisis data yang digunakan maka hasil pembahasan dikategorikan berdasarkan pesan akidah, ibadah, akhlak dan muamalah sebagai berikut:

\section{Pesan Dakwah Akidah}

Akidah yaitu keyakinan atau kepercayaan yang ada di dalam hati. Akidah merupakan sebagian syiar agama Nabi Muhammad Saw ketika pertama kali melakukan proses berdakwah. Proses akidah meliputi; iman kepada Allah Swt, malaikat, kitab yang diwahyukan kepada rasul, hari kiamat, qadha dan qadhar serta masalah yang bersangkut paut dengan keimanan (Amin, 1997:11).

Akidah dijadikan sebagai pembentuk moral manusia. Selain tentang tauhid materi akidah Islamiyah meliputi ajaran pokok dalam akidah mencakup elemen dalam rukun Iman yaitu, iman kepada Allah, malaikat, kitab-kitab, rasul, hari akhir, qadha dan qadhar. 
Dalam postingan Motivasi Hijrah, penulis menemukan 5 gambar (quote) yang terdapat nilai akidahnya, yakni pada tanggal 18, 20, 28 November dan 6, 24 Desember 2018 salah satunya yaitu:

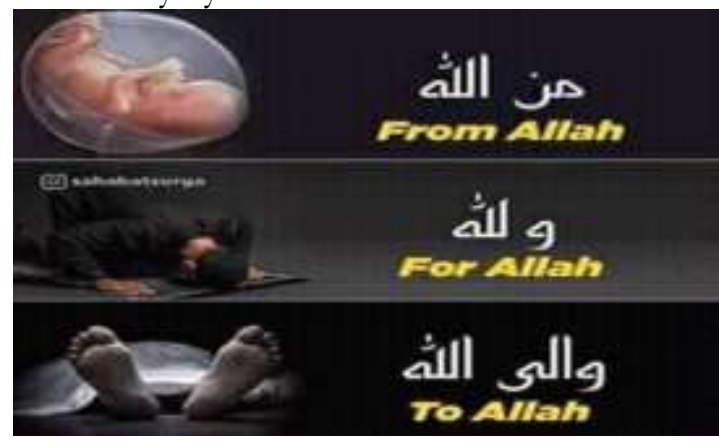

Sumber: Akun facebook Motivasi Hijrah

Gambar 2. Allah Sebagai Pencipta

Pertama, Makna Denotasi. Gambar 2 dimaknai makna denotasi dilihat dari "From Allah, For Allah, To Allah" yang menggunakan huruf Arab berwarna putih dan tulisannya menggunakan warna kuning. Simbol bayi yang berada dalam kandungan rahim seorang ibu, seorang lelaki yang sedang bersujud (gerakan shalat), dan seorang yang tertutupi oleh kain kapan menandakan seseorang sudah meninggal dunia. Background warna hitam yang di posting pada tanggal 20 November 2018 yang diambil dari akun instagram sahabatsurga.

Kedua, Makna Konotasi. Gambar 2 dimaknai konotasi "From Allah" setiap orang diberikan kesempatan dilahirkan dengan keadaan suci dan penuh kasih sayang. "For Allah" kita dilahirkan ke bumi untuk beribadah kepada Allah, sebagai pencipta segala apa yang tercipta dibumi termasuk manusia. Kewajiban untuk menegakan hukum melindungi yang lemah, dalam ajaran Islam kewajiban ditempatkan sebagai salah satu perbuatan hukum syara apabila mengerjakan akan memperoleh pahala sedangkan apabila ditinggalkan akan mendapatkan siksa seperti halnya melaksanakan sahalat adalah kewajiban yang berhubungan dengan Allah (Nata, 2014:122).

Fiman Allah: "Sungguh, Kami telah menciptakan manusia dalam bentuk yang sebaik-baiknya” (QS. At-Tin:4. Terjemahan Mushaf Aisyah, hal.597 tahun 2010). Didatangkannya manusia ke bumi untuk mengerjakan yang Allah perintahkan yaitu beribadah, bukan untuk melanggar setiap peraturan Allah. Bertaubat adalah meninggalkan kejahatan dalam segala bentuknya dan berpindah kepada jalan kebaikan karena takut kepada Allah. Bertaubat untuk memperbanyak membaca istigfar atas dosa yang telah di lakukan selama di lahirkan ke dunia (Rojaya, 2016: 54). "To Allah" Manusia diciptakan dan dikembalikan pada waktu yang ditentukan sudah menjadi tujuan manusia hidup dibumi. Sedangkan waktu, tempat dan dalam keadaan seperti apa kita tidak pernah tahu.

Tulisan Arab berwarna putih melambangkan kesan keterbukaan dan kebebasan. Warna putih sebagai kemurnian tanpa campuran apa pun yang 
memberi arti suci dan bersih. Warna kuning pada tulisannya "From Allah, For Allah, To Allah" melambangkan kehangatan dan bahagia, dengan kata lain warna ini mengandung makna ceria, bersemangat dan optimis (Jones, 2015).

Gambar bayi pada 2 manusia yang dilahirkan ke bumi sebagai tahap awal terjadinya sebuah keturunan. Gambar manusia yang bersujud melambangkan proses ibadah yang harus dijalankan selama di bumi yaitu sahalat. Sedangkan gambar orang yang sudah tertutup oleh kain kapan sebagai tanda bahwa hidup kita harus segera kembali kepada Allah. Melanjutkan kembali ke tempat asal yang sudah disiapkan untuk kehidupan kekal yaitu kepada Allah Sang Pemilik jiwa dan raga setiap manusia.

Gambar 2 dikonotasikan bahwa manusia diciptakan bertugas untuk beribadah, setiap pekerjaan apa pun didasarkan untuk ibadah. Waktu yang diberikan selama hidup di dunia harus dipergunakan dengan sebaik mungkin. Allah sebagai pencipta yang mampu membolak-balikan hati manusia sebagai manusia mulya dihadapannya. "Maka apakah kamu mengira bahwa Kami menciptakan kamu secara main-main (tanpa ada maksud) dan bahwa kamu tidak akan dikembalikan kepada kami?" (QS. Al-Mukminun:115. Terjemahan Mushaf Aisyah, hal.349 tahun 2010).

Ketiga, Makna Mitos. Gambar 2 dimaknai adanya manusia di bumi sebagai upaya untuk perjalanan beribadah kepada Allah. Jika mereka mampu menjalankan segala yang diperintahkan oleh Allah, menjauhi segala larangannya maka akan mendapat ganjaran surga. Sedangkan bagi orang yang tidak menjalankan segala perintahnya selama di bumi maka siap untuk hidup sengsara di neraka.

\section{Pesan Dakwah Ibadah}

Ibadah diartikan sebagai pelaksanaan perintah Allah dan tunduk patuh terhadap aturannya. Ibadah berusaha menghabiskan hidup dengan melakukan perintahperintah taklif dari Allah. Setiap urusan harta ataupun kepentingan diri dengan diiringi perasaan khauf dan raja dengan berniat dan disertai keikhlasan. Ibadah juga disebut sebagai pelaksanaan kewajiban untuk menghambakan diri kepada Allah (Gulen, 2014:111).

Persfektif lain yang menjelaskan bahwa ada dua macam ibadah. Pertama, ibadah kepada Allah yang tidak terbatas. Ibadah yang dilakukan dengan keadaan yang berkesinambungan atas hubungan Tuhan dan makhluknya, antara hamba dan Dzat yang disembah, serta Dzat yang Maha menyaksikan dan Maha Mengawasi makhluk. Kedua, ibadah kepada sifat-sifat Allah tertentu. Ibadah yang bersifat umun dan berimplementasi atas berbagai pemikiran dan perasaan. Ibadah membaginya dengan keinginan, tekad, niat dan keikhlasan (Gulen, 2014: 112-113).

Dalam postingan akun Motivasi Hijrah, penulis menemukan 7 gambar (quote) yang terdapat nilai ibadahnya, yakni pada tanggal 3, 18, 20, 28 November dan 16, 17, 23 Desember 2018 salah satunya yaitu: 


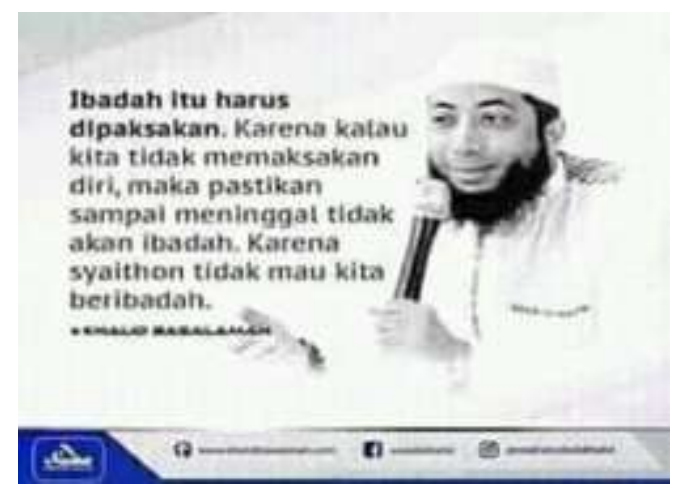

Sumber: Akun facebook Motivasi Hijrah

Gambar 3. Proses Ibadah

Pertama, Makna Denotasi. "Ibadah itu harus dipaksakan. Karena kalau tidak memaksakan diri, maka pastikan sampai meninggal tidak akan beribadah. Karena syaitan tidak mau beribadah".

Objek yang dimaknai denotasi yaitu tulisan "Tbadah harus dipaksakan, karena syaitan tidak mau beribadab". Gambar ustad yang memegang mikropon, background warna putih pada postingan, dan tulisan warna hitam yang di posting pada tanggal 18 November 2018.

Kedua, Makna Konotasi. Gambar 3 dimaknai sebagai makna konotasi karena setiap orang memiliki umur yang tidak sama dengan orang yang lainnya. Objek pertama yang dimaknai denotasi yaitu tulisan "Ibadah harus dipaksakan, karena syaitan tidak mau beribadah". Ibadah diartikan sebagai pelaksanaan perintah Allah dan tunduk patuh terhadap aturannya. Ibadah yaitu menghabiskan hidup dengan melaksanakan perintah-perintah taklif dari Allah. Urusan harta maupun diri dengan khauf dan raja yang berporos pada niat serta keikhlasan. Ibadah juga disebut sebagai pelaksanaan kewajiban untuk menghambakan diri kepada Allah (Gulen, 2014:111).

Setiap orang yang tidak menginginkan untuk mengerjakan kewajibannya untuk beribadah kepada Allah, harus diajak secara terus-menerus. Orang yang menolak untuk beribadah, tandanya ingin disamakan dengan syaitan yang tidak mau beribadah kepada Allah, suka berhura-hura dan bersikap sombong. Allah meminta umatnya untuk taat dan patuh terhadap aturannya, jika tidak menepati janjinya maka Allah datangkan murka untuk dirinya, agar mau bertaubat kepadaNya.

Apabila orang tersebut masih tidak mau mengikuti ajaran, maka ajak dengan cara yang halus untuk mengerjakan ibadah, karena sampai kapanpun kalau sudah tidak mau beribadah sejak dini tidak akan pernah mau untuk beribadah. Bahkan sampai meninggal orang tersebut masih tetap tidak beribadah. Syaitan akan merasa bahagia karena ada teman yang akan bersamanya ke neraka.

Gambar manusia (Ustad. Khalid Basalamah) sebagai orang yang menyerukan ajakan untuk orang-orang yang mau diajak kepada kebenaran. Da’i 
berusaha menyampaikan cara berdakwah lewat kekuasaan Allah, alam semesta, dan kehidupan serta menghadirkan dakwah sebagai solusi problematika yang dihadapi manusia, menggunakan cara yang tepat untuk dijadikan contoh dan dalam berperilaku agar manusia tidak salah arah (Munir dan Ilahi, 2006: 22).

Mikropon sebagai media untuk menyampaikan dawah seorang da'i kepada mad'u melalui wasilah (media) dakwah yang digunakan untuk menyampaikan materi dakwah (ajaran Islam) kepada mad'u. Menyebarluaskan ajaran Islam kepada manusia yang digunakan sebagai wasilah (Munir dan Ilahi, 2006: 32).

Umur seseorang bisa mencapai paling tua, atau bahkan bisa lebih muda dari yang seharusnya. Setiap orang memiliki jalan hidupnya masing-masing, begitupun dengan urusan mati. Sedangkan ustad hanya bertugas memberi peringatan dan mengajak kepada kebaikan. Jika masih membangkang terhadap perintah Allah, tidak mau menjalankan kewajiban sebagai seorang musim yang seharusanya maka Allah datangkan azab bagi mereka.

Warna putih pada background melambangkan kesan kebebasan dan keterbukaan. Putih sebagai warna murni tanpa campuran apa pun memberi arti suci dan bersih. Sedangkan warna hitam melambangkan keanggunan (Elegance), kemakmuran (wealht) dan kecanggihan (sopiscated), serta menjadi warna yang idependen dan penuh misteri (Jones, 2015).

Ketiga, Makna Mitos. Ibadah seseorang ditentukan oleh dirinya masingmasing, jika ingin mendapatkan kebaikan di dunia atau pun di akhirat maka jalankan perintah dan jauhi larangannya. Sesungguhnya tinggal di akhirat itu kekal dengan siksaan bagi yang meninggalkan ibadah kepada Allah.

\section{Pesan Dakwah Akhlak}

Akhlak (khuluq) adalah tabiat. Akhlak sebagai tujuan penciptaan dari seluruh makhluk, dan usaha untuk membuat pencapaian manusia dapat sejalan dengan hakikat "penciptaan" yang tujuannya mengikuti akhlak Ilahi. Keberadaan akhlak sebagai hal yang tidak dapat dipersepsi menggunakan hati, diimplementasikan oleh jiwa dan dirasakan oleh indra (Gulen, 2014: 143).

Seorang manusia yang berakhlak baik tidak bisa dilihat dari penampilan fisiknya, sebagimana menmpilkan suara hati yang sebenarnya, melainkan hanya melalui tabiat, tempramen dan karakternya. Manusia menampilkan berbagai penampilan yang berbeda-beda, tapi pada suatu saat tabiat dan karakter akan menyikap karakter mereka. Moral (akhlak) yaitu pendidikan jiwa seseorang yang mampu membersihkan sifat-sifat jelek dan dihiasi oleh kebaikan, seperti rasa persaudaraan dan tolong menolong dengan sesama (Amin, 1997:13).

Postingan quote pesan dakwah dalam akun facebook Motivasi Hijrah yang berkaitan dengan pesan akhlak, terdapat pada tanggal 13, 20 November dan 6, 16, 17, 25 Desember 2018 salah satunya yaitu: 


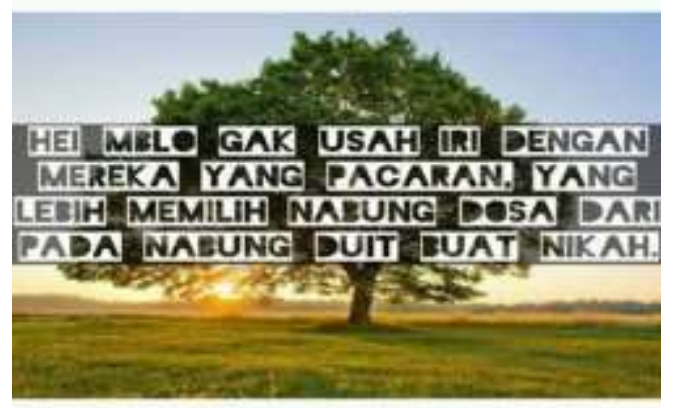

Sumber: Akun facebook Motivasi Hijrah Gambar 4. Tidak Pacaran

Pertama, Makna Denotasi. "Hei mblo gak usah iri dengan mereka yang pacaran, yang lebih memilih nabung dosa daripada nabung duit buat nikah". Objek yang bermakna denotasi pada 3.17 terdapat pada postingan yang diupload pada tanggal 16 Desember 2018 yaitu tulisan quote yang mengunakan hurup kapital berwarna putih. Objek gambar pohon besar yang terdapat dalam gambar, rerumputan hijau dan awan biru yang menghias tampilan postingan.

Kedua, Makna Konotasi. "Hei mblo gak usah iri dengan mereka yang pacaran, yang lebih memilih nabung dosa daripada nabung duit buat nikah". Motivasi untuk seseorang yang masih sendiri dan tidak menjalin hubungan dengan lawan jenisnya. Memberikan semangat untuk tidak melakukan pacaran yang sudah dilarang dalam agama Islam, menjain hubungan dengan lawan jenis berarti melanggar aturan Allah yang sudah ditetapkan. Pacaran merupakan gaya kekinian yang mengatasnamakan ta'aruf versi anak milenial. Generasi milenial menganggap semua hal yang tersebar di media sosial sebagai respresentasi dari realita dunia nyata, sehingga mereka tersinggung dan harus meluruskan sesuai pendapatnya (Sabani, 2018: 102).

Dalam Islam tidak mengenal istilah pacaran, ta'aruf dijadikan sebagai proses pertama dalam melangsungkan pernikahan. Sedangkan yang melakukan pacaran menumpuk dosa dalam kehidupannya, padahal daripada menabung dosa lebih baik menabung uang untuk menikah secara halal. Perjalanan yang akan dihadapinya pasti diridhai oleh Allah dan tidak menimbulkan maksiat.

Gambar pohon besar melambangkan keistimewaan orang yang mau berusaha menjauhi pacaran, dan lebih memilih menggunakan waktunya untuk menabung uang untuk prosesi pernikahan yang di halalkan oleh agama. Setiap perjalanan menuju pernikahan diberikan kemudahan dan keridhaan dari Allah. Warna hijau rumput melambangkan warna yang identik dnegan alam dan mampu memberi kesan santai. Berdasarkan cara pandang ilmu psikologi warna hijau membantu seseorang yang berada dalam siatuasi tertekan mampu mneyeimbangkan emosi danmempermudah berkomunikasi (Jones, 2015). 
Sedangkan warna biru pada langit memberi efek menenangkan dan diyakini mampu mengatasi insomia, kecemasan, darah tinggi dan migraine. Sedangkan tulisan warna putih melambangkan warna putih memberikan kesan kebebasan dan keterbukaan. Warna putih sebagai kemurnian tanpa campuran apa pun yang memberi arti suci dan bersih (Jones, 2015).

Ketiga, Makna Mitos. Kehidupan seorang muslim terkadang orang memiliki iman yang lemah, sehingga melakukan pacaran dan kemaksiatan, ada pula iman yang kuat dan membulatkan tekad untuk menikahi sesuai dengan ketentuan agama yang pasti.

\section{Pesan Dakwah Mua'malah}

Mua'malah merupakan ketetapan Allah yang berhubungan langsung dengan kehidupan sosial manusia. Seperti hukum waris, rumah tangga, jual beli, musyawarah dan lainnya. Mua'malah sebagai bagian komunikasi dan interaksi antar manusia dengan yang lain sebagai makhluk sosial dalam kerangka hablu min al nas. Islam merupakan agama yang nekankan mu'amalab lebih besar porsinya darpada urusan ibadah. Islam berusaha memperhatikan asfek sosial daripada asfek kehidupan ritual (Munir dan Ilahi, 2006: 27).

Postingan quote pesan dakwah dalam akun facebook Motivasi Hijrah yang berkaitan tentang muamalah, terdapat pada tanggal 16 Desember 2018.

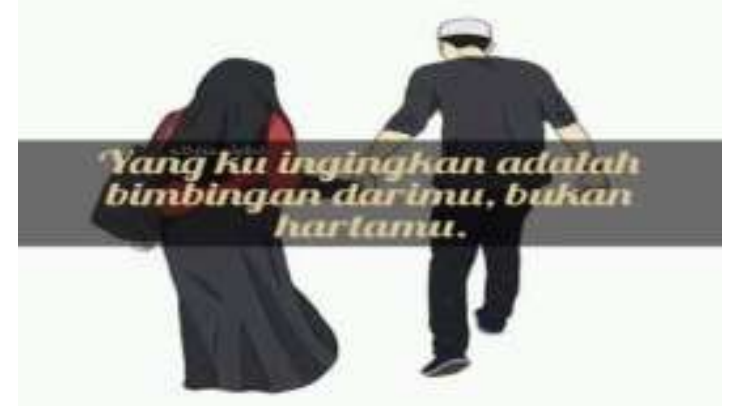

Sumber: Akun facebook Motivasi Hijrah

Gambar 5 Bimbingan Seorang Suami

Pertama, Makna Denotasi. Objek gambar 5 dimaknai sebagai denotasi "Yang aku inginkan adalah bimbingan darimu, bukan hartamu". Gambar seorang lakilaki dan perempuan yang berpegangan tangan untuk melangkah bersama-sama. Warna putih yang dijadikan background postingan akun Motivasi Hijrah yang di upload pada tanggal 16 Desember 2018.

Kedua, Makna Konotasi. "Yang aku inginkan adalah bimbingan darimu, bukan hartamu". Seorang wanita yang sudah menikah memerlukan bimbingan dari seorang suami yang menjadi imam, istri yang menginginkan bimbingan dari suaminya. Salah satu kewajiban suami adalah memberikan bimbingan agama kepada istrinya, meluruskan dari penyimpangan dan mengenalkan kepada 
kebenaran. Seseorang sebelum menjadi suami harus membekali dirinya dengan keilmuan agama yang baik agar mampu mengarahkan dan membimbing keluarganya kepada jalan yang baik

Allah telah berfirman: "W ahai orang-orang yang beriman! peliharalah dirimu dan keluargamu dari api neraka yang bahan bakarnya adalab manusia dan batu" (At-Tahrim:6. Terjemahan Mushaf Aisyah, hal. 560, tahun 2010).

Jika seorang suami memberikan harta untuk istrinya, hal itu hanya sebagai pemenuhan kebutuhan sehari-hari untuk keluarga. Keinginan istri yang sholehah yaitu bimbingan dari suaminya yang benar-benar membuat tersadar dan selalu taat pada apa yang di perintahkan oleh Allah untuk beribadah dan mengabdi kepada seorang suami. Harta dijadikan sebagai pelengkap dalam kehidupan, karena yang paling utama dalam hidup seseorang adalah keimanan yang kuat kepada Sang Pencipta.

Gambar laki-laki yang memakai peci menandakan seorang laki-laki yang beriman dan taat terhadap aturan dan perintah Allah, menggunakan penutup kepala diartikan sebagai penghormatan dan kesopanan dalam agama Islam. Sedangkan perempuan yang menggunakan jilbab yang rapi dan menutup seluruh aurat yang tidak boleh dinampakan kepada masyarakat banyak yang bukan mahramnya merpakan adab bagi seorang muslimah untuk menjaga dari hal-hal yang tidak diinginkan.

Background warna putih pada postingan melambangkan kesan kebebasan dan keterbukaan. Puth sebagai warna yang murni tanpa campuran apa pun memberi arti suci dan bersih (Jones, 2015).

Ketiga, Makna Mitos. Dalam pernikahan terkadang seorang istri meminta harta yang banyak untuk mencukupi dirinya dan kebutuhannya agar terlihat kaya dan terhormat karena harta yang dimilikinya. Harta yang dihasilkan terkadang dari cara mendaptkan dengan tidak halal.

\section{PENUTUP}

Berdasarkan fokus penelitian penulis dan analisis data yang telah dilakukan sebelumnya maka dapat ditarik beberapa kesimpulan sebagai berikut:

Pertama, Makna denotasi postingan-postingan dalam akun facebook Motivasi Hijrah yaitu kebanyakan pengambilan gambarnya dari sumber-sumber yang di buat oleh orang lain. Namun, menyesuaikan dengan tema-tema yang diangkat oleh akun facebook Motivasi Hijrah dengan mengungkap makna yang sebenarnya sesuai dengan postingan yang menyuguhkan ajakan untuk mengistiqamahkan proses perjalanan hijrah seseorang.

Kedua, Makna konotasi postingan-postingan dalam akun Motivasi Hijrah yaitu postingan tentang keutamaan seorang wanita yang berhijrah, beribadah kepada Allah sejak dini, keutamaan shalat tahajud, memohon ampunan perihal dosa-dosa, melakukan hijrah, ujian di dunia dan laki-laki yang siap menjalakan ibadah (menikah), larangan membentak seorang perempuan, larangan berbuat tabarruj, adab berdoa: larangan berdoa yang jelek-jelek untuk seorang anak, 
larangan berpacaran, memilki rasa malu, adab menundukan pandangan antar lawan jenis, dan memilih pasangan terbaik.

Ketiga, Makna mitos postingan-postingan dalam akun Motivasi Hijrah yaitu tentang ujian untuk orang berhijrah, semakin kuat keimanan seseorang makan akan semakin berat pula yang akan diberikan kepada orang tersebut karena ganjarannya yaitu surga.

Berdasarkan kesimpulan diatas maka ada beberapa saran guna membantu peneliti selanjutnya dalam mengembangkan hasil yang lebih makimal sebagai berikut:

Pertama, Untuk peneliti selanjutnya yang akan menggunakan media sosial sebagai objek penelitian, diharapkan dapat mengkaji penelitian lebih dalam lagi mengenai isi pesan dakwah di media sosial facebook dari berbagai aspek yang dapat memberikan pengaruh lebih besar bagi kelangsungan dakwah.

Kedua, Untuk pengelola akun Motivasi Hijrah konten dan gambar yang di posting lebih variatif, gambar yang diambil dari sumber orang lain yang benarbenar baik kualitasnya (tidak blur), membuat tim atau kontributor pembuat quote agar lebih terorganisir secara baik saat memposting. Tingkatkan kembali cara berdakwah melalui facebook gali pembahasan yang menarik dari yang sebelumnya dengan tanpa melepas nilai-nilai dakwahnya.

Ketiga, Untuk para aktivis dakwah agar dapat mengoptimalkan media sosial sebagai proses penyampaian dakwah secara lebih menyeluruh, agar proses penyebaran ajaran Islam dapat tersebar dari berbagai sisi. Proses dakwah yang diterima oleh masyarakat lebih mudah mendapatkan ajaran yang bersifat praktis, tidak hanya melalui pengajian yang dilaksanakan di masjid.

\section{DAFTAR PUSTAKA}

Amin, M. (1997). Dakwah Islam dan Pesan Moral. Yogyakarta: Al Amin Press.

Basit, A. (2013). Filsafat Dakwah. Jakarta: PT RajaGrafindo Persada.

Budiman, D. (2018). Dakwah pada Masyarakat Terasing Upaya Dewan Dakwah Islam Indonesia (DDII) terhadap Suku Akit Sonde Riau. Anida (Aktualisasi Nuansa Ilmu Dakwah), 18 (2), 181-193.

Fakhruroji, M. (2017). Dakwah di Era Media Baru. Bandung: Simbiosa Rekatama Media

Gulen, Muhammad Fethullah. (2014). Tasawnf Untuk Kita Semua. Jakarta: Republika Penerbit.

Hidayatullah, S. (2018). Perilaku Generasi Milenial Dalam Menggunakan Aplikasi Go-Food, Jurnal Manejemen dan Kewirausahaan, 6 (2), 240-249.

Ishaq, R. E. (2016). Pesan-Pesan Dakwah Dalam Film "3 Idiot". Ilmu Dakwah: Academic Journal for Homiletic Studies, 10 (1), 290-304.

Ismail, N. (2017). Pesan Dakwah di Media Sosial Instagram: Analisis Semiotik Pesan Dakwah di Media Sosial Instagram. Skripsi, Jurusan Komunikasi Dan 
Penyiaran Islam, Fakultas Dakwah Dan Komunikasi UIN Sunan Gunung Djati, Bandung.

Ismail, N. (2018). Pesan Dakwah tentang Nikah si Media Sosial Instagram.

Tabligh: Jurnal Komunikasi dan Penyiaran Islam, 3 (1), 22-24).

Jones, C. S. (2015), Anythink But Neutral: Using Color to Create Emosional Image. Diakses pada tanggal 27 Februari 2019, dari Website photografi.tutplus.com

Moleong, J. L. (2004). Metodologi Penelitian Kualitatif. Bandung: PT Remaja Rosdakarya.

Muhaemin, E. (2017). Dakwah Digital Akademisi Dakwah. Ilmu Dakwah: Academic Journal for Homiletic Studies, 11(2), 341-356.

Muhyiddin, A. (2002). Dakwah Dalam Persfektif Al-Qur'an Studi Kritis atas Visi dan Misi Wawasan. Bandung: CP Pustaka Setia.

Munir dan Wahyu, I. (2006). Menejemen Dakwah. Jakarta: Prenadamedia Grou

Nasrullah, R. (2015). Media Sosial Perpektif Komunikasi, Budaya dan Sosioteknologi. Bandung: Simbiosa Rekatama Media.

Nata, A. (2014). Akblak Tasawuf dan Karakter Mulia. Jakarta: PT Rajagrafindo Persada.

Pengertian Facebook, diakses pada tanggal 29 Januari 2019, dari https://id.m.wikipedia.org/wiki/facebook.

Rojaya. (2016). Studi Kitab dan Amaliah Tasawuf. Tasikmalaya: Penerbit Latifah.

Sabani, N. (2018). Generasi Milenial dan Absurditas Debat Kusir Virtual, Informasi: Kajian Ilmu Komunikasi, 48 (1), 95-108.

Shihab, Q. (2002). Tafsir Al Misbah Pesan, Kesan dan Keserasian Al-Qur'an. Jakarta: Lentera Hati.

Sukayat, T. (2009). Quantum Dakwah. Jakarta :PT Rineka Cipta.

Sukayat, T. (2009). Ilmu Dakwah. Bandung: Simbiosa Rekatama Media

Syamsuddini, dkk. (2004). Dakwah Kekinian tentang Masyarakat, Budaya Pop, Etnik dan Teknologi. Bandung

Tabroni, R. (2012). Komunikasi Politik Pada Era Multimedia. Bandung: Simbiosa Rekatama Media.

Tjandra, H. S. (2011). Sang Waktu. Jakarta: Gradien Mediatama.

Hasan, N, dkk. (2018). Literatur Keislaman Generasi Milenial Tranmisi, Apropriasi, dan Kontestasi. Yogyakarta: Pascasarjana UIN Sunan Kalijaga Press. 
A. A. Aisyah, T. Fachruddin, \& A. Aripudin 